\title{
Personal Ad Politics: Race, Sexuality and Power at The Body Politic
}

\section{David S. Churchill}

In April of 1985, subscribers of Toronto's lesbian and gay periodical The Body Politic (TBP) opened their paper to find a lengthy article exploring highly charged questions of racial and sexual politics. Regular readers of TBP had grown accustomed to sophisticated reportage of controversial issues pertaining to the lives of lesbians and gay men. What was different about the article in this particular edition of the newspaper was that it involved a conflict within TBP's own editorial collective. Appearing under the byline of TBP Collective, the article, entitled " 31 Words," included a series of lengthy memos, detailing a variety of positions relating to the publication of a classified personal ad. These memos were remarkable documents providing the paper's readers with a rare glimpse of the divergent political visions that existed inside the newspaper. The catalyst for the writing of these memos was a classified ad placed by a gay white man requesting "a young well built BM [Black Man] for houseboy." The submission of this ad initiated a debate, which revealed contrasting political visions, differing sensibilities, and deep divisions amongst members of Canada's oldest, and one of North America's most prominent lesbian, and gay publications.

This article explores the dispute that took place within $T B P$, placing it within the larger historical context of same-sex identity politics of the mid to late 1980s. In particular, I trace how the debate marks an important political and intellectual shift - a move away from an explicit commitment to sexual liberation to a politics framed by questions of difference, power, identity, and representation. Forefront in the debate was the place of race within the politics of same-sex sexuality, the "privileging" of certain identity categories, and the emergence of an inchoate queer perspective. Ultimately the debate was significant because it provided a glimpse inside one of North America's most important radical gay publications and the frustration with, and critique of, the politics on which it was founded.

The first edition of The Body Politic hit Toronto streets in late October of 1971. Begun by a small group of lesbian and gay activists, the paper billed itself as a "gay liberation newspaper." The paper was animated by individuals either participating in, or at the margins of, Toronto's counter-culture; individuals who had been involved with the alternative paper Guerilla, the newly established Community Homophile Association of Toronto (CHAT) and its more radical liberationist caucus Toronto Gay Action. ${ }^{2}$ All of these organizations, and TBP in particular, were part of Toronto's post-Stonewall political firmament which sought to revolutionize sexual attitudes, practices and laws. In 
the words of writers Ed Jackson and Stan Persky, $T B P$ "began as a radical tabloid born of political conviction and a hunger for change." 3 During the 1970s and 1980s TBP, through its collective members and contributors, constructed an activists forum for issues of same-sex sexuality, identity, community formation, discrimination, and rights discourse. ${ }^{4}$ In the process the newspaper became a venue for early gay scholarship, publishing the work of scholars such as James Steakley, Jonathon Ned Katz, John D'Emilio, and Tom Waugh. As such TBP was one of the most important, not to mention politically engaged and intellectually sophisticated, lesbian and gay periodicals in North America. ${ }^{5}$

Being a vocal and visible advocate for lesbian/gay sexuality brought TBP under the close scrutiny of the Metropolitan Toronto Police and the Office of the Attorney General of Ontario. In December of 1977, the police raided TBP offices in order to "acquire evidence" for its case against the periodical. According to the police, the newspaper was using the mail to "transmit immoral, indecent and scurrilous material." The police action, which resulted in charges against three of paper's collective members, had been prompted by the publication of an article dealing with inter-generational sexuality. ${ }^{6}$ The police not only seized files relating to the "offending" article, but also TBP's financial records, the mailing list, and a range of other materials. Over the next six years, the non-profit newspaper fought a costly legal battle - including two trials - before being acquitted of all charges in $1983 .{ }^{7}$ This was by no means the end of the debate over contentious content and censorship within the newspaper. During 1983 intense debate took place within the pages of TBP over pornography and the actions of anti-porn feminists who firebombed the Vancouver based Red Hot Video store. ${ }^{8}$ Foreshadowing the controversy to come TBP decided to run an advertisement for Red Hot Video in the June 1983 edition of the paper. Many feminists, anti-pornography advocates, and long time activists reacted angrily to $T B P$ collective's decision. In a letter of protest to $T B P$, signed by fifty-eight people, the collective was criticized for its political irresponsibility and its seeming lack of support for a social movement - the women's movement - that had a history of common cause with lesbian and gay liberation. "All of us know" the signatures wrote, "that the women's movement is a far greater ally of the gay community than Red Hot Video." As with the sex ad controversy of 1985 , the question of political constituency and the goals of particular social movements came to into sharp relief. Yet casting these debates in terms of pragmatic coalition building versus principled adherence to movement objectives assumes a fairly clear distinction between the aspirations of feminists and lesbian and gay liberationists or for that matter the politics of race and sexuality. As the personal ad controversy showed, these apparently different social and political currents were in actuality imbricated through layers of history and the operation of identity. 
The other important antecedent for the personal ad controversy was an article written by Ken Popert entitled "Race, Moustaches and Sexual Prejudice."10 Popert argued that individual sexual object choice was unfathomable and beyond conscious understanding, determined by deep and ultimately unknowable drives." "Thus, according to Popert "we are not responsible for the content of our desires," and as result, a person should not feel guilty if their desire was inflected by preferences, for or against, an individual of one or another racial group. ${ }^{12}$

It was in the aftermath of these struggles over the right to publish controversial articles and to discuss alternative and highly contested forms of sexuality that $T B P$ found itself debating issues of racism and sexual desire in the early months of 1985.

Any classified advertisement submitted to $T B P$ was not automatically published; rather each ad was subjected to a review process. Two workers read and reviewed all classified ads in light of the newspaper's advertisement policy. In 1985, the policy stipulated that ads could not be published if they were in violation of the Canadian Criminal Code or if they made explicit exclusions of particular groups or individuals. Ads making overt prohibitions such as, "no blacks," "no fats," "no fems," would therefore not be published in the paper. Moreover, TBP members would make an attempt "to educate readers to avoid inadvertent exclusions" such as "GWM (gay white man) seeks same" by contacting individuals who placed such ads and asking them whether the ad copy reflected what they really wanted to say. In seeking such clarifications $T B P$ was often able to get "problematic" ads rephrased. ${ }^{13}$ What the policy reflected was a wish to privilege certain types of representations, to have the material that was published in the paper reflect the political aspirations and cultural sensibilities of the collective. In this way, TBP's classified policy was another aspect of what sociologist Wini Brienes terms "pre-figured politics." 14 Like many alternative institutions and groups that emerged in the 1960s, and in the political wake of the decade, $T B P$ sought to have its internal structure match its philosophy and political ends. Thus the very organization of the collective and the classified advertisement policy were to match and be consistent with the goals of lesbian and gay liberation.

The worker reviewing the personal ads, Philip Solanki - one of the very few people of colour associated with $T B P$ - was unsure whether it should be forwarded for publication. Though it did not constitute an overt exclusion, Solanki found the advertiser's racial/sexual characterization troubling and decided to solicit opinions from members of the collective on whether or not to publish the ad. Some in the collective thought that the ad was acceptable and should be published; others felt that it was personally offensive but met the standard for publication. The single person of colour at $T B P$, along with a few 
others, felt that the ad was inappropriate and should not be run. Despite these concerns and the explicit opposition of some of TBP membership, the personal ad was published in the February edition of the newspaper. ${ }^{15}$

The story of the classified ad, however, did not end there. A meeting was arranged between collective members and a number of other community based lesbian/gay organizations to discuss the matter in greater detail. The meeting with representatives of Lesbians of Color, Zami, Gay Asians of Toronto, and $T B P$ collective occurred a few days after the publication of the newspaper's February issue. The divisions that had emerged over the publication of the ad resurfaced over the course of the evening. Characterizing the mood of the three hour meeting, Alan Li found that the "attitudes of certain collective members were far more offensive and dangerous than the ad itself." 16 Echoing Li's assessment, Richard Fung observed that the community representatives found the attitude of certain collective members to be "patronizing" and "arrogant." According to Li those members of TBP collective who supported the publication of the ad asked Zami and Gay Asians to explain what made the ad offensive and to provide a rational for pulling the ad from publication. This created a situation, in Li's view, where community representatives felt they were pleading a case, forced to legitimate their opposition to the ad's publication, and their own concerns about racism. Li continues, "[a]t the meeting we were made to feel that our arguments were non-representative, our objections hysterical, and our feeling defensive." ${ }^{77}$ As the meeting continued the personal ad controversy was cast in sharper terms, ones which lesbians/gays of colour perceived as a choice between "gay" liberation and the politics of anti-racism and racial identity, a choice they were not only unwilling but also unable to make.

Between the publication of the February edition of $T B P$ and the appearance of the April edition, meetings inside and outside the collective continued to question the decision to publish the personal ad. In an effort to clarify their own positions, respond to issues raised at the meetings, and sway the opinions of other collective members, various individuals circulated lengthy memos outlining arguments for and against publication of the ad and inquiring into the constitutive aspects of sexual desire, race, and the project of liberation. These memos provide an intimate glimpse into a highly charged moment within the recent history of lesbian and gay politics. Finally, these documents reveal both an impassioned defense and a vigorous critique of lesbian/gay liberation, as well as nascent queer calls to reconceptualize the politics of same-sex sexuality.

As mentioned earlier, the decision to publish the personal ad occurred in the immediate aftermath of protracted legal battles over TBP's right to publish and distribute controversial material. In the debate over the ad, three of the four principals involved in the paper's criminal trials took strong positions in favor 
of running the ad. These three men, Gerald Hannon, Ken Popert, and Rick Bćbout, each marshaled gay liberationist arguments in support of the advertiser's right to express himself and TBP's responsibility as a liberationist periodical to publish the ad. Going beyond mere demands for the right of free speech and free expression, these men sought to link the publication of the ad to the very purpose of $T B P$ - that the paper was a rare forum for sexual expression, however contentious that expression might be, and as such needed to publish the ad.

Writing over a decade after the publication of the classified ad, TBP collective member Rick Bébout cast the debate in terms of institutional power and the refusal of some of the veteran members of the editorial collective to acknowledge their position as "insiders," at least in terms of the working and management of the paper. According to Bébout, the crisis of gay liberation and $T B P$ was due to the fact that "most early gay liberationists figured they had a working grasp on "identity" - unitary, or binary at best - as a transformative project: "the homosexual" was to be recreated as "the liberated gay man." 18 After years of struggling against the police, the State, and anti-homosexual activists such as Anita Bryant, there was little acknowledgement of the power and privilege enjoyed by this generation of gay activists who had come of age during the early 1970s. Bébout's analysis confirms Gerald Hunt's ethnographic observations of TBP as a collective workplace. In Hunt's study he found that a generational tension existed between the "older" liberationists at the paper and "newer" workers and collective members who were committed to "a broader range of social causes than gay liberation," and as a result somewhat less inclined to commit body and soul to the paper. ${ }^{19}$ Though this distinction runs the risk of oversimplification there were some generational tensions being played out during the debate over the classified ad. More than a generational split, however, the debate around the sex ad became a struggle over the divergent understandings of sexual liberation and sexual politics and their operation within the specific historical field of Toronto during the mid 1980s.

\section{IN DEFENSE OF LIBERATION}

In his memo, collective member and veteran gay activist, Gerald Hannon argued that ads such as the "contentious ad," and even those that are "far worse," should be accepted for publication. Such a decision would be in keeping, he argued, with the sort of sexual politics that $T B P$ has for years "quietly espoused" and should - in his view - continue to champion. Hannon acknowledged that the relationship depicted in the ad was inequitable and that it was based on a real historical circumstance, namely that of chattel slavery. That

said, one could not, he argued, wish away things that are found to be morally, 
politically, or sexually problematic. "The fact is," he wrote, "[a contentious] act will never be cleaned up, no one will ever know the act has to be cleaned up, unless [it] goes on." In Hannon's view, the personal ad revealed an awkward truth - that racism was part of social reality and as such its existence needed to be acknowledged and debated within a public arena. Implicit in Hannon's argument was a psychological conceptualization of personal politics in which socalled "private" ideas and desires were to be opened up and aired in the public realm. Only through such a process of discovery and revelation, of transparency and honesty, he argued, could lesbians and gays debate sexual relations, understand personal motivations, and transform unjust predicaments. Hannon's repression thesis linked liberation to a larger post-war social critique in which the mechanisms and conventions of modern life were seen to be coercive and oppressive. ${ }^{20}$ Thus, racism, sexism, and homophobia were types of social pathology, part of a systemic mechanism of oppression experienced in and through everyday lives that needed to be exorcised through acts of public expression and corresponding intellectual scrutiny. As such it was not just individuals who "come out" in gay liberation but a myriad of ideas, feelings, and desires. ${ }^{21}$

In his memo, Hannon expressed his commitment to contentious opinions by writing in a manner deliberately designed to offend. Utilizing racist tropes of "quiet and exquisite Asians" and "big black studs" Hannon argued that these sorts of sentiments reflected real "feelings" - which, according to Hannon "intercede... particularly at sexual moments when feelings are more likely to surge forward than...rational beliefs on the matter." 22 Hannon's arguments were consistent with both liberationist and counter-cultural notions of authenticity and genuineness. ${ }^{23}$ Indeed, it was through the quest for authenticity, "To Be Real" in the words of the disco anthem, that gay liberation was most closely linked to other cultural and political movements of the of the late 1960s and early 1970s. Writer and long time queer activist Jeffrey Escoffier has pointed out the centrality of authenticity to the gay liberation. In particular, Escoffier points to the influential liberationist work of Dennis Altman and Kate Millet for their promotion of "the discovery and expression of one's repressed self as the true or authentic self." 24 Thus, the privileging of difficult and even ugly sentiments because of their authenticity was a way of getting at inner truths and ultimately overthrowing forms of repression that dominate or seem to dominate our everyday. Moreover, the ultimate project for the liberationist was not just to "come out" as homosexual but, rather to transcend the narrow categories of "homosexual" and "heterosexual," to free one's self of sexual categorization all together ${ }^{25}$ As former student activist and Gay Liberation Front member Carl Wittman wrote in his widely circulated 1970 "Gay Manifesto," most "of us have mixed identities, and have ties with other liberation movements." Thus for 
Wittman, gay liberation was not only about securing social space and rights for queers but transforming sexual behavior throughout all of society. ${ }^{26}$

While Hannon expressed his support for the publication of the ad in terms of personal politics, author Rick Bébout developed a more pragmatic argument. In his memo Bébout attempted to address both the "need" for TBP to publish the ad and his concern and appreciation for the social context of the controversy. Bébout laments, "when oppression in those more established categories is at issue, sexuality becomes potentially divisive, it's a downright dangerous luxury, a concern of the privileged." ${ }^{27}$ Such a position grows out of gay liberationists' frustration with the New Left's subordination of issues of sexuality, not to mention gender, to supposedly more important concerns for social justice, civil rights, and peace. ${ }^{28}$ Bébout's uneasiness with calls to solidarity did not, however, lead him to a critique that rejected the privileging of particular social and political categories. Instead, he defended this privileging by arguing for a self-interested particularism. "I think the exploration of sexuality as it is" he wrote, "is one of our most fundamental jobs. Not the only one, certainly, but one only we can do from our particular perspective, one that no one else can do for us, and one that transcends even as it depends upon the creation, development and defense of our space." ${ }^{29}$ For Bébout TBP exists to provide a forum where issues of sexuality, especially same-sex sexuality, can be explored, debated, and contested by a community of interest. Because only a few venues exist for discussions of lesbian/gay sex - and since these were constantly at risk there was a special need for $T B P$ to make greater allowances for matters of sexuality then for issues such as race and class. ${ }^{30}$

Bébout's privileging of issues of sexuality was premised on the existence of a broadly conceived lesbian and gay community. The conflict over the sexual ad revealed, however, that many individuals who "identified" as gay or lesbian nonetheless felt excluded from this community. As the opponents of publishing the personal ad would point out, the invocation of the language of community had the effect of eliding racial difference making their own experiences incommensurable with being lesbian or gay.

One of the most hotly contested arguments advanced in support of publishing the personal ad was Ken Popert's contention that "desire is inviolable." This was a classic claim of gay liberation, one which sought to free sexualobject choice from a restrictive regime of heterosexuality. ${ }^{31}$ For Popert, a long time editor with $T B P$, the cause of gay liberation was the safeguarding of desire in the face of an oppressive social system that sought to deny, criminalize, and medicalize sexual impulses. Moreover, Popert saw the move by the ad's opponents as an act of censorship, an attempt to limit and define what was and was not appropriate sexuality, erotic expression, and desire. ${ }^{32}$ Yet, as another collective member pointed out, the editorial process itself was a limiting and cen- 
soring one where choices about what to include and what to exclude were routinely made. ${ }^{33}$

Popert mentions how he utilized motifs of sexual violence, coercion, verbal abuse, and degradation in S/M sex. He rhetorically wondered if his actions were homophobic, if they reflected some deeper aspect of self-hatred? Stating that he had no answers for these questions, Popert nonetheless asserted that there "is nothing politically incorrect about these activities." For him sexual desire was "just there like quasars or protons," part of the nature of things in the world. "We can learn about these things by studying them," he goes on to say; "right now, I think that the study of desire is the most interesting thing there is; it is not there to be morally evaluated and either glorified or condemned. It is the point of departure for understanding gay people... Desire is inviolable." ${ }^{34}$ For Popert, working socially and culturally significant themes into sexual fantasy was what animated these fantasies, gave them a profound resonance, and allowed access to the most intimate conceptualizations of the self. Thus, a fantasy involving historically real circumstances such as gay bashing, racism, or slavery only added to the potency of the sexual play. "My working hypothesis is that fantasy is the subjective experience of keenly felt external tensions and contradictions" he wrote, "[f]antasy is what allows people to live with these contradictions." For Popert, the historically real practices of subjugation and the utilization of socially grounded relations of power frame $S / M$ sex in such a way as to afford a therapeutic way of living with domination and the desire to dominate, in effect, forming ways of living with those "tensions and contradictions" that are presumptively there in our everyday life.

As such, personal freedom, the ability to express contentious ideas and to practice supposedly deviant sexuality, was of critical importance to many members of $T B P$ collective, especially those who had seen that freedom threatened by the State in its campaign against $T B P$ and again in the bath house raids of 1981. Moreover, liberationists such as Popert and Hannon sought to insulate sexuality from social criticism because it represented a powerful foundational and authentic aspect of being. For these two activists the protection of individual erotic autonomy was essential to the larger project of sexual liberation. ${ }^{35}$ For Bébout these claims to the primacy of sexuality were limited and stemmed from the need to preserve forms for sexual expression and contentious sexuality. Ultimately, both the conceptualizations of sexual liberation, the authentic and the pragmatic, supported the publication of the classified ad.

\section{THE POVERTY OF LIBERATION POLITICS}

Just as the liberationists employed a number of positions in favor of the publication of the classified ad, the ad's opponents marshaled a variety of arguments 
against its inclusion in the paper. As the controversy grew within the paper, competing positions and memos being circulated and debated among collective members took on an increasingly personal and sharp tone. Collective member Tim McCaskell was clearly angered by the language used by the pro-publication faction and their polemic response to the controversy. Focusing on Ken Popert's memo, McCaskell argued that the desire to have a black houseboy was not fantastical play but a very real circumstance. Unlike two consenting gay men who might role play S/M sex, the ad did not ask for the creation of a fantasy or for the acting out of scripted sex roles. Individuals, McCaskell continued, did not advertise for heterosexist homophobes to come over, abuse, humiliate, and beat them up. "The ad," according to McCaskell, "calls for a real relationship based on historical stereotypes and made possible by existing social inequalities." 36 McCaskell turned the liberationist project back on the advocates for the publication of the ad charging that their protection of one individual's desire has the effect of denying equality and standing to another.

Building on this point, McCaskell argued that most radical liberationists would concede that certain types of sexual behavior and desire are not condoned or supported.

While the exploration and expression of our sexualities is an important part of community development it does not follow that anyone's desire is somehow inviolable. We do not support the desire, which fulfils itself in the practice of rape, no matter how much of a turn-on rape may be for rapists. There are clearly acceptable and unacceptable expressions of desire. Its effects on the lives and rights of others is a clear limitation. ${ }^{37}$

The question of boundaries and the limits of an individual subject's autonomy was central to the praxis of sexual liberation. McCaskell positioned his argument not on a legal prohibition against rape (though clearly he supports such laws) but on an ethical standard that abhors the violation of one individual subject's freedom by another.

The proponents of publishing the ad tended to be veterans of the early gay liberationist movement of the late 1960s and early 1970s. The members of the collective who were opposed to the running of the ad tended to be younger, individuals who became involved in same-sex political work during the late 1970 s and early 1980s. This generational difference and shift in thinking was obvious in some of the circulated memos. One such important intellectual shift was the growing influence of post-structuralism, especially the work of French philosopher Michel Foucault. Collective member, and sociologist, Allan O'Connor utilized Foucault's conceptualization of pleasure in his critique of 
Popert's "inviolability of desire" questioning why "we talk about "desire" as if it were more fundamental than anything else? Why don't we understand sexuality," he continued, "simply as a matter of pleasure that belongs with other pleasures a body can enjoy - dancing, cating, renovating a house, cooking, watching a movie? We find pleasure in many ways, even in many different kinds of sexual play. And don't we change? Stop doing certain things and get into others?" Here O'Connor challenged the ontological certainty of desire, the need to protect and secure its expression for the continuation of same-sex subjectivity. In this, he followed Foucault in advocating a protean conceptualization of pleasure situated in an open and fluid sexual economy. ${ }^{38}$ of all the memo authors, O'Connor came closest to articulating a "queer" theoretical critique of the ad's publication. In arguing against naturalized conceptualizations of desire, O'Connor called for lesbian and gay identified subjects to make strategic choices. Bluntly put, this meant choosing not to re-inscribe racist tropes in sexual play, images, or fantasies. Sex, accordingly, was not a set of deeply ingrained natural impulses but practices learnt, developed, and articulated in a specific historical context, a context that could and did change over time.

O'Connor's memo was just one by a group of activists who were opposed to the publication of the classified ad. Another TBP contributor, Mariana Valverde, picked up another of Foucault's themes - that of power - in her letter in opposition to the classified ad. "The laissez-faire approach," wrote Valverde, "conceals such important things as social power, oppression and domination - and of course it makes sense that those who have power (in this case, editorial and political power to define the issues of gay people in Canada) would try and pretend that there is no power." ${ }^{39}$ Individuals such as filmmaker John Grayson, began to disassociate themselves from $T B P .{ }^{40}$ These conflicts in and around the mission of the paper ultimately precipitated the paper's demise in 1987. Over a decade and a half after the publication of the classified advertisement, the issues that provoked the political firestorm remain unresolved. How should organizations, institutions, communities, and states reconcile the demands of collective and individual rights? This has been a core conflict within the history of the Left since the 1960s.

Another important challenge to the doxa of gay liberation emerged out of local and intellectual debates around racial and ethnic identity. In his forceful memo in opposition to the publication of the personal ad, Toronto video maker Richard Fung questioned the axiomatic assumption of sexual liberation, which celebrates almost any form of sexual expression as emancipatory. Echoing feminist critiques of the so-called "sexual revolution," Fung wondered "who" it was that the "emancipation of desire" benefits. Just as feminists questioned the rhetoric of free love because it did not challenge male privilege or the pre- 
sumptive right of men to access women's bodies, Fung asked who got empowered by the articulation of sexual fantasies. After all, sexual fantasies don't exist in a privileged realm divorced from the operation of everyday life. "It is only when we examine [sexuality] in a real social context," Fung writes, "that we begin to see it as a problem." ${ }^{41}$ As such, Fung was calling for a historical understanding of sexuality, one that acknowledges that sexual expression and experience take place within cultural and social fields mediated by power. Thus sexuality was not a privileged realm divorced from the inequalities that permeate everyday life. As Fung asserted, "I cannot justify one person's pleasure at someone else's expense" nor should such conduct be condoned in the name of lesbian/gay liberation. "To champion the cause of uninhibited desire," wrote Fung "without addressing the impact of racism and sexism in the sexual arena is to call for the entrenchment of white male privilege." 42

Fung's reading of the personal ad debate was suggestive of Audre Lorde's challenge to white feminists, questioning calls of horizontal belonging, in the face of social hierarchies of racial exclusion. ${ }^{43}$ The failure to recognize racial difference was for Fung, just another way that history and social context were ignored in the personal ad debate. Moreover, a statement such as "we as lesbians and gays understand homophobia but we don't understand racism," underscores the ontological whiteness of the imagined lesbian and gay communities. ${ }^{44}$ Fung's conceptualization of difference, his demand for recognition, his critique of the universalizing claims of gay liberation, and his call to historicize racial characterizations, were a rejection of assimilation into this imagined community. Fung's views reflected the changing political landscape of lesbian and gay organizing in Toronto during the 1980s. During this period lesbians and gay men of colour established organizations that explicitly linked issues of race, ethnic difference, and sexuality. In a gesture that highlighted the influence of African American author Audre Lorde's writing, a Toronto based Black Canadian group called itself Zami, a name inspired by the title of Lorde's groundbreaking memoir. ${ }^{45}$ Throughout the 1980 s anti-racist organizing by queers of colour was part of a larger transnational political, intellectual, and literary movement that linked issues of race, sexuality, belonging, and class with questions of identity, citizenship, and power. ${ }^{46}$

More recently, literary critic Philip Brian Harper has noted that there is a limited degree to which "many men of color" will identify with terms such as gay or queer. According to Harper, the term gay "conjures up in the minds of many who hear it images of a population that is characteristically white, male and financially well off: thus it can actually efface rather than affirm the experiences of women and men of color." ${ }^{17}$ Writing in a similar mode, scholar Lisa Lowe has observed that a predominant narrative of citizenship, nation, and history serves to exclude Asian Americans who "by definition cannot be imagined 
as sharing in America." 48 As African American scholar Ron Simmons has noted, the position of African American homosexuals was particularly vexed by the perception among some Black intellectuals that same-sex sexuality was a form of whiteness "a problem caused by white oppression," often excluded, alienated and ignored by predominately white gay institutions. ${ }^{49}$ As J.R.G. DeMarco noted, blacks within white dominated gay culture were still, as writer Ralph Ellison observed a generation earlier - invisible. ${ }^{50}$

For liberationists the shift of the focus away from sexuality and desire seemed to presage the dissipation of the movement itself. Yet for feminists, people of color, transgender activists, and working-class queers, a move away from a narrow focus on sexual identity was crucial to the development of an inclusive praxis open to multiple and shifting identities. The "black houseboy" of the classified ad was a figure that was simultaneously sexualized and racialized, as most sexual subjects are. Indeed, the whiteness of the 1970s gay "clone" had a presumed status, not invisible but rather present, unacknowledged, a given. One would not, for example, describe someone as a "white clone" because a clone was already assumed to be white. Such constructions carried with them unacknowledged racializations where all individuals are normatively assumed to be white unless otherwise marked.

Not surprisingly, lesbian and gay men of colour began to organize as a way of disrupting the ubiquitous whiteness of queer public culture. In Toronto during the 1980s and early 1990s numerous anti-racist groups sought to provide support, services, and cultural work. ${ }^{51}$ These groups challenged the given public culture of Toronto's lesbian and gay community by making the experience of people of colour, living in the Diaspora visible, recognizable, and present. Yet the institutional vitality and growth of these communities, as well as the changing demographics of Toronto, were only marginally represented in the pages of $T B P$, the paper remained largely the effort of white gay men.

A core tension of many new social movements has been whether time, resources, and energy should be focused on a specifically defined and limited set of issues and goals or through a political praxis which makes connections to other causes that see the divisions between certain types of goals as illusory and false. The modern lesbian and gay liberation movement itself emerged out of a larger "Movement" against modern forms of social injustice, discrimination, and repression. Its initial premise assumed that the cause of liberation was explicitly linked to these to concerns, part of a shared project that had economic, legal, cultural, and personal dimensions. In Toronto during the early 1970s, activists with Toronto Gay Action (TGA) were active participants in protests against U.S. President Richard Nixon and the Vietnam War. The first articles about gay liberation were published in an underground newspaper with ties to the counterculture and the New Left. ${ }^{52}$ Yet inclusive "Movement" poli- 
tics were often not that inclusive. Women, people of colour, lesbian and gay men often felt that their aspirations and goals were being shunted off and not being given full or equal voice. The founding of TBP itself emerged out of frustration with the limits of collective mass movement politics. Many of the founders of TBP had in fact been involved with the underground counter-cultural newspaper Guerilla. Throughout 1971, the lesbian and gay members of Guerilla grew increasingly frustrated with what they saw as their marginalization within the newspaper, as well as the placement and the editing of lesbian and gay articles. This frustration with predominately male radicals who dominated the paper was shared by a group of feminist at Guerilla who eventually broke away to the periodical The Other Woman in the early months of 1972.53

Throughout the 1970s and 1980s, gay and lesbian liberationist fought against stereotypes of same-sex sexuality, which they saw as negative, disfigured, and unfair. In 1971, for example, members of Toronto Gay Action and $T B P$ picketed the $C B C$ for the airing of a documentary that they saw as perpetuating negative stereotypes. ${ }^{54}$ The protest to $\mathrm{CBC}$ management and outside the $\mathrm{CBC}$ building faulted the documentary for not being representative of a broader range of lesbian and gay life, for concentrating too much on sex and promiscuity, and for "denigrating so-called feminine qualities in men and applauding so-called feminine qualities in women." 55 Even more famously, members of TBP participated in the North American wide campaign, by gay men and lesbians, against Anita Bryant and her attempt to "save the children of America" through the negative stereotyping of same-sex sexuality and the repeal of civil rights ordinances protecting lesbians and gay men. Key for liberationists was the rejection of external definitions and characterizations of their own identity, sexual practices, and behaviors. As sometime TBP contributor Vito Russo noted in his ground-breaking book The Celluloid Closet, representation of lesbians and gay men on film had historically been "politically indefensible and aesthetically revolting." What was needed, he argued, were films with characters "who happened to be gay" and that explored the way "their lives intersect with the dominant culture." 56

In their introduction to TBP anthology Flaunting It, Ed Jackson and Stan Persky noted that "affirming homosexual identity is a political act and challenging the social and institutional control of our lives is a political struggle." 57 Indeed, the control of images, representations, and identity had been a core project of lesbian and gay liberation. American philosopher and cultural critic Cornell West has noted that African Americans have historically struggled to "present themselves to themselves and others as complex human beings, and thereby to contest the bombardment of negative, degrading stereotypes put forward by White supremacist ideologies." 58 Yet, as the classified ad debate brought into sharp relief the struggle over identity, representation, and the 
boundaries of community was not only about external forces acting on homosexual subjects. Rather, it involved an immanent critique of the relationships between same-sex subjects and the operational effects of freedom and choice. The political struggle set off by the ad's publication punctured the universalistic liberal rhetoric of common cause pitting calls for sexual liberty against those of sexual equality.

By $1987, T B P$ had ceased publication due in large part to its substantial debt and the exhaustion of key collective members. ${ }^{59}$ Its successor, the popular and entertainment oriented Xtra, is not an overtly political publication nor is it run as a collective enterprise. Rather Xtra is a business, run by paid staff, with a traditional hierarchical management structure similar to any number of commercially oriented community based newspapers. What the dispute within TBP revealed was that lesbian and gay liberation - conceived as a critique of systemic sexual oppression and an expression of individual rights - was insufficient in addressing the complex operation of multiple identities, class, and subject positions experienced by individuals in modern society. As long as "gay" remained an autonomous liberal subject attempting to expand personal rights in a social and political field, liberationist politics, narrowly conceived, failed to account for the ways that same-sex subjects were part of symbolic and political economies mediated by race. The decline in liberationist politics and the emergence of a supposedly more nuanced and fluid politics of sexual identity did not however put an end to the contentious politics of sexual and gender identity. Attempts by activists in the early 1990s, for example, to form new political organizations such as Queer Nation, did not resolve the privileging of sexuality over categories such as race, gender, and class. As historian Steven Maynard observed at meetings of Queer Nation in Toronto during the early 1990s, issues of race and class difference were considered within a paradigm of "individual notions of identity." 60 Thus, the operation and constitution of race, gender, and class were narrowly conceived in terms of individual rights rather than collective or group rights or perhaps more significantly in light of the inter-relationship of these protean social categories.

As the classified ad controversy within TBP illustrated, the recognition of a common enemy, living under a regime of sexism and sexual regulation does not necessarily provide a unified or shared experience of domination. Indeed, the rhetoric and demands of "community" has the capacity to efface difference in the demand for social solidarity. The contentious politics that the publication of the ad elicited was not new to TBP. In point of fact the sex ad debate was a continuation of a larger political dispute around political ethics, consent, and power that had created conflict between the predominately male members of the newspaper's collective and lesbian feminists. The personal ad proffered a relationship overdetermined by history, identity, and obligation. In evoking the 
image of the houseboy, the ad's author moved from a description of a potential sexual partner to a type of subjected person, one framed by the spectre of institutional slavery and/or colonial privilege; a relationship caught in a racialized calculus of power connected to a historically specific social hierarchy. The very scriptedness of the ad denied the possibility of agency and self-creation, offering instead a dynamic of dependency, an all too familiar historical location for people of colour in their encounter with global political economy, be they residing inside or outside Western industrialized societies. ${ }^{61}$ The Canadian philosopher Charles Taylor advanced the notion of the "politics of recognition" to characterize the way that groups demand standing within the rights discourse of liberal democratic societies. Yet such recognition must go beyond the apprehension of political subjects within a polity, and simplistic liberal formulation that social equality can be achieved through a process of ontological acknowledgement, where standing in the supposedly broad horizontal field of the nation's civil society is granted by already empowered subjects who dole out membership. Recognition must also entail an understanding of the historical operation of power, the myriad of ways that people are situated in economic and social hierarchies produced in specific contexts. ${ }^{62}$ Finally, the ad was in clear violation of the core ethic of sexual liberation - that being a commitment to collective, individual, and inter-subjective forms of identity, practice, and experience in the face of systemic domination and heteronormativity. In the privileging of the sexual desire and subjectivity of the ad's author and to a lesser extent the advocates for publishing within $T B P$ effaced the subjectivity of the desired "object" and thus provided a forum for racism in one of North America's most politically engaged venues for lesbian and gay thought.

At the end of his book, The Fire Next Time, the American writer James Baldwin argued that people of "conscious," both black and white, "must, like lovers, insist on, or create, the consciousness of others" to end "the racial nightmare" of modern life. ${ }^{63}$ As historian Thomas Holt has asserted "racial ideologies and constraints are shaped by the historical-material moment" but this same contextual moment provides "materials and means for the resistance to those ideologies and constraints." ${ }^{64}$ The great tragedy of the entire controversy was that $T B P$, for all its great strengths, its activist members, and its intellectual force, was unable to transform itself into a site of such resistance, a place where racism and the operation of racial ideologies were understood not merely as a counterpart to sexism and sexual regulation but as an inexorable part of heteronormativity, the very matter of an activist newspaper dedicated to the cause of sexual liberation.

I would like to thank Rick Bébout, Robin Jarvis Brownlie, Matti Bunzl, George Chauncey, Tina Chen, Henry Heller, Adele Perry, Elizabeth Povinelli, Hesh Tropper, the members of the Andrew Sawyer Seminar on Sexuality and Identity at the University of Chicago and the editors and anonymous readers at Left History for their comments, criticisms and suggestions. 
IThe Collective, "31 Words" The Body Politic (April 1985), 29.

2 Peter Zorzi, Queer Catharsis: Notes for an Anecdotal Guide to Canadian Gay Archives Accession (Toronto: CLGA/The Author, 1992); Rick Bébout, On the Origins of the Body Politic197I (\& before) to 1974 (\& beyond) [online document] http://webhomeidirect.com/ r rbebout/oldbeep/beepint.htm. For a detailed and informative chronology of gay and lesbian activity in Toronto during these years see Donald W. McLeod, Lesbian and Gay Liberation in Canada: A Selected Annotated Chronology, 1964-1975 (Toronto: ECW Press/Homewood Books, 1996). For a history of Guerilla see Ron Verzuh, Underground Times: Canada's Flower Child Revolutionaries (Toronto: Deneau, 1989).

${ }^{3}$ Ed Jackson and Stan Persky, eds., "Introduction," Flaunting It (Toronto: Pink Triangle Press, 1982), 2.

${ }^{4}$ For more on the struggle for same-sex rights see: Didi Herman, Rights of Passage: Struggles for Lesbian \& Gay Legal Equality (Toronto: University of Toronto Press, 1994); Gary Kinsman, The Regulation of Desire: Homo and Hetero Sexualities $2^{\text {nd }}$ edition (Montreal: Black Rose Press, 1998); Miriam Smith, Lesbian and Gay Rights in Canada: Social Movements and EqualitySeeking, 1971-1995 (Toronto: The University of Toronto Press, 1999). For a more international and comparative analysis of lesbian and gay politics see Barry Adam, The Rise of the Lesbian and Gay Movement $2^{\text {nd }}$ edition (Boston: Twayne, 1995).

5 Steven Maynard, "In Search of 'Sodom North": The Writing of Lesbian and Gay History in English Canada, 1970-1980" Canadian Review of Comparative Literature/ Revu Canadienne de Littérature Comparée (March/June 1994); Rodger Streitmatter, Unspeakable: The Rise of the Gay and Lesbian Press in America (Boston: Faber and Faber, 1995).

"Gerald Hannon, "Men Loving Boys loving Men" The Body Politic (November 1977). For a detailed discussion of this controversy see Beckie Ross, The House The Jill Built: A Lesbian Nation in Formation (Toronto: The University of Toronto Press, 1995), 165-170.

${ }^{7}$ Gary Kinsman, Regulation of Desire, 339.

${ }^{8}$ On November 23, 1982 an anti-pornography group, The Wimmin's Fire Brigade, fire bombed three outlets of the adult video chain Red Hot Video in and around the city of Vancouver. Two stores sustained damage and the third was destroyed. There was extensive coverage of the bombing pornography and the issue of censorship in TBP. Jackie Goodwin, "Fanning the flames: Fire Brigade vs Red Hot" The Body Politic (January/February 1983); Tim McCaskell, "Pornography and Prohibition" The Body Politic (April 1983), 33-34; Craig Patterson, "Uncertainties follow Red Hot Fire Brigade Charges" The Body Politic (March 1983), 11; Craig Patterson, "Attack and Retreat: porn control law in doubt" (May 1983), 11. For an first person account of the Wimmin's Fire Brigade see: Ann Hanson, Direct Action: Memiors of an Urban Guerrilla (Toronto: Between the Lines Press, 2001).

${ }^{9}$ Nancy Abrams et al., The Body Politic (July/August 1983), 4. In their letter the signatures note they represent diverse opinions on the issue of pornography but nonetheless reject $T B P$ 's decision to associate itself with the Red Hot Video chain through display advertising.

${ }^{10}$ Ken Popert, "Race, Mustaches and Sexual Prejudice" The Body Politic (June 1983), 34.

${ }^{11}$ At the time of this debate during the mid 1980s Popert's position reflected the dominant view that sexuality was an innate drive. As Popert argues "[w]e are not responsible for it, for its being 
the way it is; we are responsible for controlling it." Ken Popert, "Race, Mustaches and Sexual Prejudice" The Body Politic (June 1983), 34.

${ }^{12}$ Ken Popert, "Race, Mustaches and Sexual Prejudice" The Body Politic (June 1983), 34.

${ }^{13}$ The Body Politic Collective, "31 Words" The Body Politic (April 1985), 11.

${ }^{14}$ Wini Breines, Community and Organization in the New Lefi 1962-1968 (New York: Praeger, 1982), 3-6.

$15 \mathrm{Ibid}$.

${ }^{16}$ Alan Li, The Body Politic (April 1985), 30.

${ }^{17}$ Alan Li, The Body Politic (April 1985), 30.

${ }^{18}$ Rick Bébout, "Promiscuous Affection: A life in the Bar, 1969-2000,"; available from $h t t p: / / w e b-$ home.idirect.com/ rbebout/bar/1985a.htm; Internet; accessed January 30, 2001.

${ }^{19}$ Gerald Callan Hunt, "Division of Labor, Life Cycle and Democracy in Worker Co-operatives" Economic and Industrial Democracy Vol. 13 (1992): 32.

${ }^{20}$ These arguments emerged in American sociology and neo-Freudian humanist psychology during the mid to late 1950s and were very influential on 1960 s social movements and the counter-culture. In particular the totalizing system of advanced industrial capitalism, its laws and institutions, were seen as repressive and psychologically corrosive. See Herbert Marcuse, Eros and Civilization: A Philosophical Inquiry into Freud (Boston: Beacon Press, 1955); Paul Goodman, Growing Up Absurd: Problems of Youth in the Organized System (New York: Random House, 1961). On the importance of these social critiques see Morris Dickstein, Gates of Eden: American Culture in the Sixties (Cambridge MA: Harvard University Press, 1997), 51-88; Andrew Jamison and Ron Eyerman, Seeds of the Sixties (Berkeley CA: University of California Press, 1994), 118-128.

21 It is important not to reduce or simply equate "sexual liberation" with libertarian politics. Sexual liberation as it was articulated in $T B P$ and within more radical and activist gay and lesbian circles was a structural political critique that saw the social architecture of society as repressive and limiting. "Gay liberation" in the words of an early TBP editorial, "is a socio-political force working for a society free of unnecessary repression and oppressive political structures. As gay liberationists, we challenge the dominance of the nuclear family as the basic political unit of institutionalized sexism.... As gays, our very existence challenges the major behavioural manifestations of the status quo. In order to create a world where human relationships can transcend the politics of power, in which alienation and persecution cease to be the basic aspects of human communications, we must all work to break down the historical myths and institutions responsible for the inhumanity of society." As such sexual liberation is not merely a liberal plea for tolerance and equality under the law but a revolutionary struggle to challenge the normative frames of modern sexuality such as the patriarchal family and the criminalization and patholization of non-reproductive sexuality. In contrast libertarians believe that individuals are endowed with natural rights and that governments are in effect necessary evils that must exist to protect those natural rights. What is key for libertarians is that government must be as small and limited as possible so that it functions to preserve individual autonomy and prevent anarchy, without infringing on that same individual autonomy. The purpose of constitutions and a system of laws is to provide a check on the power of government and thus restrain and limit its sovereignty, which is derived only through the consent of the people. On libertarian political thought see Robert Nozick, Anarchy, State and Utopia (New York: Basic Books, 1974). 
${ }^{22}$ Gerald Hannon, The Body Politic (April 1985), 32.

${ }^{23}$ On the importance of authenticity to the New Left and the counter-culture see Doug Rossinow, Politics of Authenticity: Liberalism, Christianity and the New Left in America (New York: Columbia University Press, 1998). For the Canadian context see Myrna Kostash, Long Way From Home: The Story of the Sixties Generation in Canada (Toronto: Lorimer, 1980); Doug Owram, Born at the Right Time: A History of the Baby-boom Generation (Toronto: University of Toronto Press, 1996). 24 Jeffrey Escoffier, American Homo: Community and Perversity (Berkeley: University of California Press, 1998), 125-126.

25 Jonathon Ned Katz, "Introduction 1995 Edition," Donald Teal, Gay Militants (New York: St. Martin's Press, 1995), xviii-ix.;

${ }^{26}$ Carl Whitman, "Gay Manifesto" in Mark Blasius and Shane Phelan, We Are Everywhere: A Historical Sourcebook of Gay and Lesbian Politics (New York: Routledge, 1997), 380-388.

${ }^{27}$ Rick Bébout, The Body Politic (April 1985), 31.

28 Bébout's argument echoes that of British liberationist Andrew Hodges and David Hutter. "Recognition of the open participation and encouragement of gay people" according to Hodges and Hutter, " has often been demonstrated by a display of no less open homophobia." Andrew Hodges and David Hutter, With Downcast Gays (Toronto: Pink Triangle Press, 1977). Hodges and Hutter's pamphlet was a major intellectual influence on the members of TBP during the mid-1970s. The importance of the pamphlet was underscored by the fact that the Pink Triangle Press, TBP's parent company, was the North American publisher. For a history of the fractured relationship between the New Left and lesbian gay liberation see, Terrance Kissock, "Freaking Fag Revolutionaries" Radical History Review 62 (1995): 104-134. Indeed, calls for the subordination of "narrowly" defined identity in the pursuit of "common dreams" continue to be made by New Left veterans such as Todd Gitlin. See Todd Gitlin, The Twilight of Common Dreams: Why America is Wracked by the Culture Wars (New York: Metropolitan Books, 1995).

${ }^{29}$ Rick Bébout, The Body Politic (April 1985), 31 .

${ }^{30}$ To clarify his own position and get more input Bébout contacted members of the Atlanta chapter of Black and White Together. According to Bébout the group hotly debated the classified ad but failed to reach a consensus on whether or not to publish. Renaldo Walcott has cautioned against simply imposing U.S. based notions of racial politics or assuming that the political concerns of African Americans are commensurate with those of Black Canadians. Nonetheless, as the sex ad controversy would illustrate, the flow of critical thinking on race and sexual between the U.S. and Canada was and continues to be significant. See Rinaldo Walcott, Black Like Who? Writing Black Canada (Toronto: Insomniac Press, 1997).

31 Barry Adam, Rise of a Lesbian and Gay Movement; Michael Bronski, Culture Clash: The Making of Gay Sensibility (Boston: South End Press, 1984), 198-200.

32 CLGA 87-004/1 Body Politic Staff Minutes: Ken Popert, Memo February 4, 1985

${ }^{33}$ CLGA 87-004/1, "Memo to the collective from collective secretary cb [Chris Bearchell], no date.

${ }^{34}$ Ken Popert, "31 Words" The Body Politic (April, 1985), 32.

${ }^{35}$ Though this formulation was highly individual it is not strictly libertarian in that Probert and Hannon have a conceptualization of the collective needs of same-sex subjects rather than simply the securing of individual rights by autonomous actors within modern society. 


\section{Churchill}

${ }^{36}$ Tim McCaskell, "31 Words," The Body Politic (April, 1985), 31.

${ }^{37}$ Tim McCaskell, "31 Words," The Body Politic (April, 1985), 31.

38 The work that develops this point most fully is the first volume of Foucault's History of Sexuality. In this work Foucault proffers a devastating critique of psychoanalytic drive theory that naturalize supposedly inherent desires. See Michel Foucault, The History of Sexuality: An Introduction translated by, Robert Hurley (New York: Vintage Books, 1978). Also see an interview with Michel Foucault, "Interview with Alexander Wilson and Bob Gallagher" in Gay Spirit; see also David Halperin, Saint Foucault (New York: Oxford University Press, 1996).

39 Marianna Valverde, The Body Politic (May 1985), 4.

${ }^{40}$ CLGA 87-004/1 The Body Politic from John Greyson January 30, 1985.

41 Richard Fung, The Body Politic (April 1985), 31.

42 Richard Fung, The Body Politic (April 1985), 31.

${ }^{43}$ See Audre Lorde, Sister Outsider (Trumsanburg NY: Crossing Press, 1984); Audre Lorde, Zami: A New Spelling of My Name (Watertown, MA: Persephone Press, 1982).

${ }^{44}$ Richard Fung, The Body Politic (April 1985), 31.

${ }^{45}$ Audre Lorde, Zami: A New Spelling of My Name (Watertown, Mass: Persephone Press, 1982).

${ }^{46}$ Himani Bannerji, ed., Returning the Gaze: Essays on Racism Feminism and Politics (Toronto: Sister Vision Press, 1993); Paul Gilroy, There Ain't No Black in the Union Jack (Chicago: University of Chicago Press, 1991); bell hooks, Black looks (Boston: South End Press, 1992); Barbara Smith ed., Home Girls: A Black Feminist Anthology (New York: Kitchen Table Press/ Women of Color Press, 1983); Makeda Silvera, Fireworks: The Best of Fireweed (Toronto: The Women's Press, 1986).

47 Philip Brian Harper, Are We Not Men: Masculine Anxiety and the Problem of African-American Identity (New York: Oxford, 1996), 205. Historian Gregory Conerly has explored the dialectical operation of conflicting and competing affiliation and identity, the twin problems of black homophobia and "lesbigay" racism. In Conerly's view the danger of identity politics arises from the identification with one group to the exclusion of the other. Gregory Conerly, "The Politics of black lesbian, gay and bisexual identity" in Brett Beemyn and Mickey Eliason, eds., Queer Studies : $A$ Lesbian, Gay, Bisexual \& Transgender Anthology (New York: New York University Press, 1996), 134-136.

48 Lisa Lowe, Immigrant Acts (Durham NC: Duke University Press, 1996), 6.

49 Ron Simmons, "Some thoughts on the challenges facing black gay intellectuals" in Essex Hemphil and Joe Beam, eds., Brother to Brother: New Writings by Black Gay Men (Boston: Alyson Publications, 1991), 211.

${ }^{50}$ J.R.G. DeMarco, “Gay Racism” in Michael J. Smith ed., Black Men/White Men (San Francisco: Gay Sunshine Press, 1983).

${ }^{51}$ There were numerous organizations and groups founded in the $1980 \mathrm{~s}$ that sought to incorporate anti-racist, feminist and queer sexuality into their mandate. For example Sister Vision Press, founded in 1985 by Makeda Silvera and Stephanie Martin, has published numerous books by women of colour, lesbian and bi-sexual women. Groups such as Khush, a lesbian and gay South Asian organization have, through their sponsorship of the Salaam Toronto and Desh Pardesh cultural festivals, highlighted the diversity of South Asian sexuality, erotic expression, and identity. Another group, 
Gay Asians Toronto (GAT), founded in 1980, has similarly sought to provide a cultural and politi$\mathrm{cal}$ venue for Asian queers living in Toronto.

${ }^{52}$ Guerilla was the first forum for gay liberationist articles and texts in Toronto. The newspaper covered the founding of the first post-Stonewall liberationist organization the University of Toronto Homophile Association as well as republishing influential liberationist tracts such as American Carl Whitman's "Gay Manifesto." A number of individuals who would be involved TBP and LBGT political activism such as: Holly Devor, Charlie Dobie, Jearld Moldenhauer, Herb Spiers, and Peter Zorzi, were involved with Guerilla, See "UTHA," Guerilla (December 1970): 5; Carl Whitman, "Gay Manifesto: Part One," Guerilla (July 14, 1971): 12-13; Carl Whitman, "Gay Manifesto: Part Two," Guerilla (July 21, 1971): 8-9: Christopher St. Commemoration," Guerilla (June 23, 1971) 4; Lavender Kid, "Hey Faggot!" Guerilla (January 1971): 9; Jearld Moldenhauer, "In the Pouring Rain" Guerilla (September 1971, 4; Peter Zorzi, "Screwed at the Pretzel," Guerilla (September 15 1971): 11; Richard. "Gays Rap \& Zap with CBC: Hill Hits Sexist TV Program," Guerilla (December 15 1971): 3. For more information of Guerilla and other alternative newspapers in Canada during the 1960 s see Verzuh, Underground Times.

${ }^{53}$ Becki Ross, The House That Jill Built: A Lesbian Nation in Formation (Toronto: The University of Toronto Press, 1995), 38-39.

${ }^{54}$ Letter from Toronto Gay Action to CBC Television", December 5, 1971, 89-08/01, Toronto Gay Action Papers, Canadian Lesbian and Gay Archive. The letter was signed by representatives of TGA, the University of Toronto Homophile Association, the Community Homophile Association of Toronto and Jearld Moldenhauer on behalf of The Body Politic editorial collective.

55 Ibid.

56 Vito Russo, The Celluloid Closet: Homosexuality and the Movies, revised edition (New Yorker: Harper and Row Publishers, 1987), 325.

${ }^{57}$ Ed Jackson and Stan Persky ed., Flaunting It!, 7.

${ }^{58}$ Cornell West, "The New Cultural Politics of Difference" in Simon During, ed., The Cultural Studies Reader (London: Routledge, 1993), 210.

${ }^{59}$ Pink Triangle Press, TBP's parent company continues to thrive as the publisher of Xtra a commercially oriented LGBT tabloid in Toronto. Pink Triangle is also the owner of a lucrative phone sex line that has allowed Xtra to publish editions in Western Canada and Ottawa. See Rick Bébout, http://webhome.idirect.com/ rbebout/bar/1988a.htm

${ }^{60}$ Steven Maynard, "When Queer is Not Enough: Identity \& Politics" Fuse (Fall 1991), 15. For more on fractured politics of Queer Nation see Lauren Berlant and Elizabeth Freeman, "Queer Nationality" in Michael Warner, ed., Fear of a Queer Planet: Queer Politics and Social Theory (Minneapolis: The University of Minnesota Press, 1993), 193-229.

${ }^{61}$ On the place immigrant women from developing countries in the global political economy see: Saskia Sassan, Globalization and Its Discontents: Essays of the New Mobility of People and Money (New York: The New Press, 1998); Cynthia Enloe, The Morning After: Sexual Politics at the End of Cold War (Berkeley: University of California Press, 1994).

${ }^{62}$ For recent critiques of Charles Taylor's communitarian liberalism see: Himani Bannerji, The Dark Side of the Nation: Essays on Multiculturalism, Nationalism and Gender (Toronto: Canadian Scholars Press, 2000), 125-150; Elizabeth A. Povinelli, "Notes on Gridlock: Genealogy, Intimacy, 


\section{Churchill}

Sexuality" Public Culture 14.1 (2002): 215-238

63 James Baldwin, The Fire Next Time (New York: Dial Books, 1963), 118.

${ }^{64}$ Thomas C. Holt, The Problem of Race in the $21^{\text {st }}$ Century (Cambridge: Harvard University Press, 2001), 120 